\title{
RELAYOUT TATA LETAK GUDANG BARANG DENGAN MENGGUNAKAN METODE DEDICATED STORAGE
}

\author{
Delia Meldra ${ }^{1 *}$ dan Husor Mangibul Purba \\ 1,2 Progam Studi Teknik Industri Universitas Putera Batam, \\ Jalan R. Soeprapto, Muka Kuning, Batam, Kepulauan Riau \\ *Email:dmeldra@gmail.com
}

\begin{abstract}
The results of this research is to calculate the total reduction in material handling withinthe warehouse current conditions, on the proposals 1 and 2 and counting the proposedreduction in the total distance of material handling. The results obtained in the initialconditions is $1305.1 \mathrm{~m}$, whereas the proposed one condition, namely a decrease of $1137.07 \mathrm{~m} 168.03 \mathrm{~m}$ with a percentage of $12.87 \%$ decline, and on condition that the proposed $2933.28 \mathrm{~m}$ decreased by $371.83 \mathrm{~m}$ from the initial conditions with the percentage of $28.50 \%$ decline.This result is a total trip takes material handling for storing and sending existing paintwarehouse.
\end{abstract}

Keywords: Dedicated Storage, Handling Material, Space Requirement

\section{Pendahuluan}

PT Nexelite CP Indonesia adalah sebuah perusahaan yang bergerak di bidang industrie shipyard. Sebagai salah satu perusahaan shipyard yang ada di kota Batam, PT Nexelite CP Indonesia dipercayakan untuk menyelesaikan beberapa proyek pembuatan module ataupun kapal kecil sampai ukuran besar. Perusahaan ini memiliki beberapa gudang yang digunakan untuk menyimpan atau menampung persediaan seperti blasting equipment, painting equipment, wellding equipment dan untuk memenuhi permintaan dari lapangan atau konsumen. Berdasarkan survey yang dilakukan, permasalahan yang dihadapi oleh PT Nexelite CP Indonesia yaitu terletak pada gudang paint atau cat dimana tidak adanya aturan tertentu tentang penempatan barang jadi atau paint tersebut dari sistem gudang, akibatnya tata letak penyimpanan dan penyusunan dilakukan secara acak atau sembarangan tergantung pada posisi gudang yang kosong, tanpa mempertimbangkan aktivitas produk, ukuran produk, jenis paint dan indikator lainnya. Tentu hal ini akan menyulitkan material handling dalam mengatur produk yang akan diambil atau disimpan digudang produk paint karena diperlukan waktu untuk pencarian produk dan jarak tempuh yang tidak tetap setiap kali ada pengambilan dan penyimpanan paint serta terjadipenumpukan paint yang berlebihan. Pada saat produk paint baru masuk gudang, inimenyebabkan tidak ada tempat atau slot yang kosong sehingga diletakkan di gang gudang dan mengakibatkan stacker atau trolly sulit untuk melintas dan menghambat aktivitas material handle. Berdasarkan pemaparan diatas perlu dilakukan penataan lokasi penyimpanan produkpaint atau cat pada gudang produk jadi dengan menggunakan salah satu metode penataan lokasi penyimpananan yaitu metode dedicated storage, sehingga aliran produk yang masukdan keluar dari gudang dapat terkoordinasi dengan baik dan penggunaan daerah penyimpanan pada gudang menjadi optimal. Metode dedicated storage merupakan metode penataan produk dengan menempatkan satu produk pada satu lokasi penyimpanan saja (fixed location) (Permana et al., 2013: 272). Penetapan ini didasarkan pada perbandingan aktivitas tiap produk dengan kebutuhan ruangyang dibutuhkan produk tersebut kemudian didapatkan urutan produk dari yang terbesar sampai terkecil. Tujuan dari metode ini adalah untuk memberikan usulan perbaikan tata letakgudang produk jadi yang lebih fleksibel terhadap pemindahan barang atau paint di gudang, mendapatkan rancangan tata 
letak penyimpanan produk jadi yang efektif, meminimalkan jarak transportasi pada gudang, menghemat pemindahan barang dan pengaturan barang dalam gudang produk jadi.

\section{Landasan Teori}

Pengaturan dan tata letak suatu gudang dapat dilihat dalam beberapa bentuk kebijakan penyimpanan yang ditentukan perusahaan, dimana metode terbaik yang akan diambil tergantung pada karakteristik item (Hadiguna dan setiawan, 2008: 157). Kebijakan-kebijakan tersebut antara lain:

1. Kebijakan penyimpanan acak (Random Storage Policy)

2. Kebijakan penyimpanan tetap (Dedicated Storage Policy)

3. Cube Per-Order Index Policy

4. Class Based Storage Policy

5. Kebijakan penyimpanan pangsa (Shared Storage Policy)

Dedicated Storage atau yang disebut juga sebagai lokasi penyimpanan yang tetap (fixedslot storage), menggunakan penempatan lokasi atau tempat simpanan yang spesifik untuk tiap barang yang disimpan (Hadiguna dan Setiawan, 2008:170).

Penempatan pada metode ini didasarkan pada perbandingan aktivitas tiap produk(throughput) dengan kebutuhan ruang (space requirement) yang butuhkan produk kemudian didapatkan urutan produk dari yang terbesar sampai terkecil. (Permana, et al 2013: 272)

\subsection{Tata Letak Pabrik}

Tujuan dari tata letak pabrik secara garis besar menurut (Wignjosoebroto 2009: 68) adalah mengatur area kerja dan segala fasilitas produksi seekonomis mungkin untuk operasi produksi yang aman dan nyaman sehingga dapat menaikkan moral kerja dan performance operator.

\subsection{Gudang}

Gudang memiliki beberapa misi, yaitu (Hadiguna dan Setiawan.2008:153):

1. Menjaga persedian sebagai penyeimbang antara penjadwalan produksi dan permintaan.

2. Gudang sebagai penyalur dalam daerah pesanan dengan jarak transportasi terpendek dan untuk memberikan jawaban cepat akan permintaan.

3. Gudang digunakan sebagai tempat akumulasi dalam kegiatan pendistribusian .
Tujuan dari sistem pergudangan adalah untuk mengurus dan menyimpan barang-barang yang siap untuk didistribusikan dan disalurkan. Perancangan gudang yang baik dapat meminimalkan biaya pengadaan dan pengoperasian sebuah gudang serta tercapainya kelancaran pada proses pendistribusian barangdari gudang ke konsumen (Wignjosoebroto: 2009: 286)

Ada beberapa karakteriktik gudang berdasarkan maetrialnya, yaitu Raw material storage, Working process storage, Finished good product storage, Storge for supplies, Finish Parts storages, Salvage, Scrap and Waste.

Dalam hal ini gudang yang menjadi titik fokus yaitu gudang barang jadi.

\subsection{Kebijakan Penyimpanan Dalam Gudang}

Menurut Hadiguna (2008: 157), pengaturan dan tata letak suatu gudang dapat dilihat dalam beberapa bentuk kebijakan penyimpanan yang ditentukan perusahaan, dimana metode terbaik yang akan diambil tergantung pada karakteristik item.

\subsection{Dedicated Storage}

Dedicated Storage atau yang disebut juga sebagai lokasi penyimpanan yang tetap (fixed slot storage), menggunakan penempatan lokasi atau tempat simpanan yang spesifik untuk tiap barang yang disimpan (Hadiguna, 2008:170).Hal ini dikarenakan suatu lokasi simpanan diberikan pada satu produk yang spesifik.

\subsection{Space Requirment}

Space requirment adalah produk yang ditempatkan pada lokasi yang lebih spesifik dan hanya satu jenis produk saja yang ditempatkan pada lokasi penyimpanan tersebut (Permana, 2013:274). Rumus yang dipakai dalam perhitungan kebutuhan ruang adalah :

$S j=\frac{\text { rata }- \text { ratapenerimaan }}{\text { kapasitasblok }}$

\subsection{Throughput}

Throughput (Aktivitas) adalah pengukuran aktivitas atau penyimpanan yang sifatnya dinamis, yang menunjukkan aliran dalam penyimpanan. Istilah throughput digunakan sebagai ukuran jumlah aktivitas storage dan retrieval yang terjadi perperiode waktu. Pengukuran Throughput dilakukan berdasarkan pengukuran aktivitas penerimaan dan 
pengiriman dalam gudang produk jadi rata - rata per hari (Permana,222013:274). Rumus yang digunakan adalah :

$T j=\left(\begin{array}{l}\text { rata }- \text { rata } \\ \text { penerimaan } \\ \begin{array}{l}\text { kapasitas } \\ \text { angkut }\end{array}\end{array}\right)+\left(\begin{array}{l}\text { rata }- \text { rata } \\ \text { pengiriman } \\ \text { kapasitas } \\ \text { angkut }\end{array}\right)$

\subsection{Penempatan Produk}

Penyusunan produk pada dedicated

Storage:

1. Mengurutkan produk berdasarkan rasio kebutuhan throughput ( $\mathrm{Tj})$ danSpace requirment $(\mathrm{Sj})$ produk tersebut. Rumus untuk menghitung $(\mathrm{T} / \mathrm{S})$ :

$\frac{T}{S}=\frac{\text { Throughput }}{\text { Spacerequirment }}$

2. Menghitung nilai jarak (dk) dari tiap lokasi penyimpanan.

3. Tempatkan produk 1 pada lokasi penyimpanan $\mathrm{S} 1$ yang memiliki nilai $\mathrm{dk}$ terkecil, tempatkan produk 2 pada lokasi penyimpanan yang belum ditempati, S1 yang memiliki nilai $\mathrm{dk}$ terendah berikutnya, dan seterusnya sampai semua produk mendapatkan tempat masing-masing.

Rumus yang digunakan untuk jarak perjalanan :

(Wignjosoebroto 2009)

$J T=(S j) \times\left(\begin{array}{l}\begin{array}{l}\text { Jaraktotalblok } \\ \text { perproduk }\end{array} \\ S j\end{array}\right)$

\section{Metodologi Penelitian}

\subsection{Teknik Pengumpulan Data}

Pada penelitian relayout ini menggunakan pendekatan observasi dan literature. Hal ini bertujuan untuk mengumpulkan informasi dan data penelitian.

\subsection{Metode Analisis Data}

Proses analisis data berurutan berdasarkan flowchart berikut:

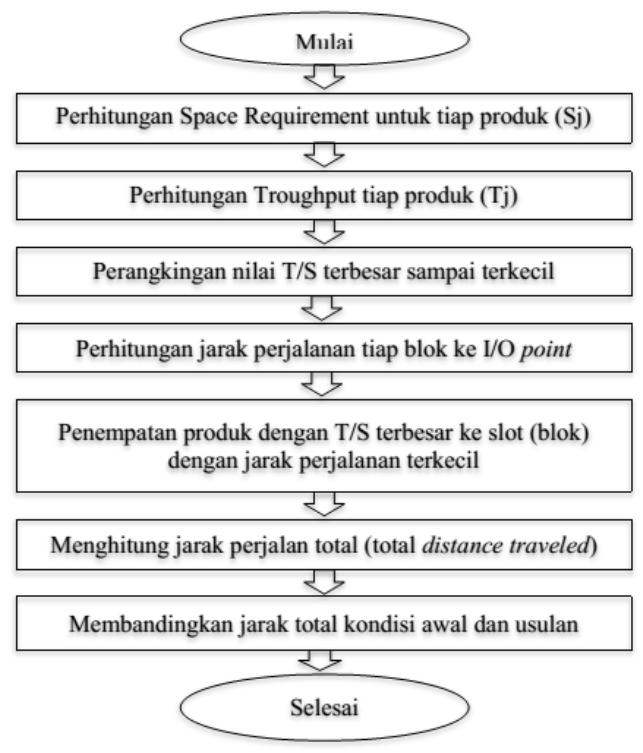

Gambar 2Flow Chart Pengolahan Data

Metode pendekatan menggunakan dedicated storage - throughput.

\section{Hasil Penelitian}

\subsection{Data Jenis Produk}

Tabel 1. Data Jenis Produk Paint

\begin{tabular}{|c|c|c|c|c|c|}
\hline $\begin{array}{l}\mathrm{N} \\
\mathrm{o} .\end{array}$ & Code & Deskripsi & Warna & $\begin{array}{l}\text { Isi } \\
\text { (Lt) }\end{array}$ & $\begin{array}{c}\mathrm{Jml} \\
\text { per } \\
\text { Pall } \\
\text { et }\end{array}$ \\
\hline 1 & $\begin{array}{c}\text { ENA3 } \\
00\end{array}$ & $\begin{array}{c}\text { Intershield } \\
300\end{array}$ & Bronze & 12,5 & $\begin{array}{l}48 \\
\text { Tin }\end{array}$ \\
\hline 2 & $\begin{array}{c}\text { ENA3 } \\
01\end{array}$ & $\begin{array}{c}\text { Intershield } \\
300\end{array}$ & $\begin{array}{c}\text { Alumin } \\
\text { ium } \\
\text { RAL }\end{array}$ & 12,5 & $\begin{array}{l}48 \\
\text { Tin }\end{array}$ \\
\hline 3 & $\begin{array}{l}\text { PHB } \\
898\end{array}$ & $\begin{array}{c}\text { Intershield } \\
990\end{array}$ & $\begin{array}{l}5012 \\
\text { Light } \\
\text { Blue }\end{array}$ & $\begin{array}{c}17,1 \\
4\end{array}$ & $\begin{array}{l}48 \\
\text { Tin }\end{array}$ \\
\hline 4 & $\begin{array}{c}\text { PHC } \\
243\end{array}$ & $\begin{array}{c}\text { Intershield } \\
990\end{array}$ & $\begin{array}{c}\text { RAL } \\
2008 \\
\text { BtRedo } \\
\text { range } \\
\text { RAL }\end{array}$ & $\begin{array}{c}17,1 \\
4\end{array}$ & $\begin{array}{l}48 \\
\text { Tin }\end{array}$ \\
\hline 5 & $\begin{array}{c}\text { PHZ } \\
007\end{array}$ & $\begin{array}{c}\text { Intershield } \\
990\end{array}$ & $\begin{array}{l}9010 \\
\text { Pure } \\
\text { White }\end{array}$ & $\begin{array}{c}17,1 \\
4\end{array}$ & $\begin{array}{l}48 \\
\text { Tin }\end{array}$ \\
\hline 6 & $\begin{array}{c}\text { PHX } \\
67 \mathrm{H}\end{array}$ & $\begin{array}{c}\text { Intershield } \\
990\end{array}$ & $\begin{array}{l}\text { RAL } \\
7047 \\
\text { Tele } \\
\text { Grey }\end{array}$ & $\begin{array}{c}17,1 \\
4\end{array}$ & $\begin{array}{l}48 \\
\text { Tin }\end{array}$ \\
\hline
\end{tabular}

Pada penelitian ini gudang yang digunakan adalah gudang penyimpanan produk paint dari supplier. 


\subsection{Data Penerimaan dan Pengiriman Produk}

Kegiatan atau aktivitas yang terjadi di dalam gudang yaitu paint meliputiproses penerimaan, penyimpanan, dan pengiriman produk paint. Data penerimaan merupakan jumlah paint yang masuk ke gudang dalam bentuk tin. Data pengiriman adalah data paint harian yang keluar dari gudang penyimpanan untuk dikirim ke konsumen atau ke lapangan atau yard. Data yang didapatkan ialah data rata-rata penerimaan dan pengiriman produk paint selama 1 tahun.

Tabel 2. Data Rata-rata Penerimaan Paint

\begin{tabular}{ccc}
\hline No. & Code & $\begin{array}{c}\text { Rata-rata penerimaan } \\
\text { paint (Tin) }\end{array}$ \\
\hline 1 & ENA300 & 293 \\
2 & ENA301 & 209 \\
3 & PHB898 & 14 \\
4 & PHC243 & 19 \\
5 & PHZ007 & 19 \\
6 & PHX67H & 26 \\
\hline
\end{tabular}

\subsection{Informasi Gudang}

Luas gudang produk jadi paint keseluruhan sekitar 312 m2 (24 m X 13 m). Paint disimpang di dalam gudang dengan diatas pallet, yang masing-masing memiliki jumlah Tin yang berbeda dalam setiap palletnya. Paint pindahkan dengan bantuan stacker. Proses pemindahan paint didalam gudang mengunakan stacker bila jumlah paint yang akan dipindahkan banyak jika sedikit hanya menggunakan hand jack. Susunan penyimpanan di gudang saat ini masih tidak teratur karena tidak ada tempat spesifik untuk menyimpan 1 jenis paint. Paint yang masuk akan disimpan pada lahan atau slot yang kosong, dan penumpukan juga terjadi sampai batas maksimum tinggi paint. Penumpukan tanpa memperhatikan jenis paint akan mempersulit pengambilan produk dan dimungkinkan memperpanjang jarak material handling.

Lokasi penyimpanan digambarkan dalam bentuk area template, memiliki slot atau blok yang digunakan untuk menyimpan paint. Dalam $1 \mathrm{blok} / \mathrm{slot}$ dapat menampung 1 pallet dengan tumpukan 1 pallet ke atas. Layout gudang dapat dilihat pada gambar.

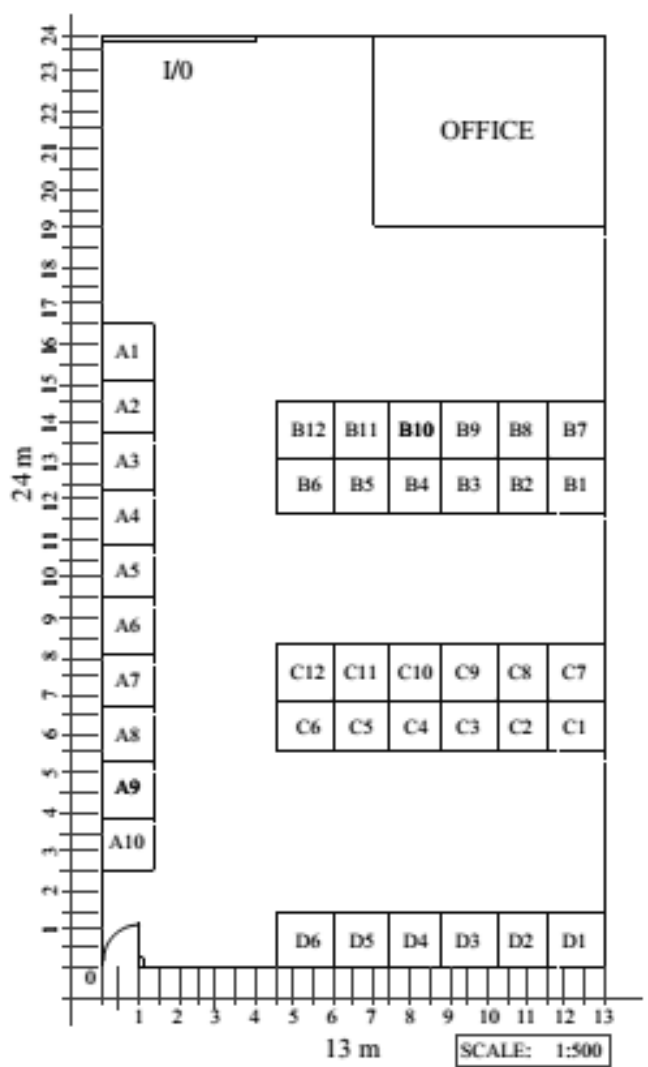

Gambar 3. Layout Gudang Paint

\subsection{Space Requirment (SR)}

Paint yang disimpan di gudang akan disusun diatas pallet. Pallet dipakai untuk penyimpanan 1 jenis produk, dimana jumlah yang dapat disusun padapallet berbeda setiap jenis. Pallet tersebut akan di letakan ditiap-tiap slot, 1 slotatau blok dapat menampung 1 pallet dan 1 pallet tumpukan keatas. Kebutuhanruang atau blok untuk tiap jenis paint dapat dilihat di tabel 3 .

Tabel 3. Space Requirment (SR) Tiap Paint

\begin{tabular}{cccccc}
\hline N & Code & Jml & $\begin{array}{c}\text { Rata-rata } \\
\text { penerimaan } \\
\text { paint }\end{array}$ & $\begin{array}{c}\text { SR } \\
\text { teorit } \\
\text { is }\end{array}$ & $\begin{array}{c}\text { SR } \\
\text { blok }\end{array}$ \\
\hline 1 & ENA3 & 48 & 293 & 3,052 & 4 \\
& 00 & Tin & & 1 & \\
2 & ENA3 & 48 & 209 & 2,177 & 3 \\
& 01 & Tin & & 1 & \\
& PHB & 48 & 14 & 0,145 & 1 \\
3 & 898 & Tin & & 8 & \\
& PHC & 48 & 19 & 0,197 & 1 \\
4 & 243 & Tin & & 9 & \\
& PHZ & 48 & 19 & 0,197 & 1 \\
5 & 007 & Tin & 19 & 9 & \\
& PHX & 48 & 26 & 0,270 & 1 \\
6 & $67 H$ & Tin & 26 & 8 & 1 \\
\hline
\end{tabular}

Contoh perhitungan kebutuhan blok (space requirment) untuk paint ENA300:

Kebutuhan rata-rata untuk penyimpanan paint ENA300 adalah 293 drum. 
Satu pallet maksimal menampung 48 drum dan satu blok dapat menampung 146 pallet dan 1 tumpukan keatas, maka space requirment paint ini adalah:

$S j=\frac{293}{48 \times 2}=3,0521 \approx 4$

Untuk memudahkan pengambilan paint, maka dalam satu slot atau blok hanya digunakan satu jenis paint.

\subsection{Perhitungan Thorughput}

Aktivitas penerimaan/pengiriman pada gudang paint menggunakan stacker dan hand jack sebagai material handling. Dalam sekali pengangkatan dapat mengangkat 1 pallet berisi 48 drum untuk ukuran paint yang besar dan 180 drumuntuk paint ukuran kecil. Maka rata-rata aktivitas penerimaan/pengiriman paint dikonversi kedalam satuan pallet dengan data produk per pallet sama dengan yang dijelaskan di sub bab sebelumnya. Perhitungan throughtput untuk tiap jenis paint dapat dilihat di tabel 4 .

Tabel 4. Throughput tiap jenis paint

\begin{tabular}{|c|c|c|c|c|c|}
\hline $\begin{array}{l}\mathrm{N} \\
\mathrm{o} .\end{array}$ & Code & $\begin{array}{c}\text { Rata-rata } \\
\text { penerima } \\
\text { an paint }\end{array}$ & $\begin{array}{l}\text { Rata-rata } \\
\text { pengirim } \\
\text { an paint }\end{array}$ & $\mathrm{Jml}$ & $\begin{array}{l}\text { Thoro } \\
\text { ughput }\end{array}$ \\
\hline 1 & $\begin{array}{c}\text { ENA3 } \\
00\end{array}$ & 293 & 157 & $\begin{array}{c}48 \\
\text { Tin }\end{array}$ & 10 \\
\hline 2 & $\begin{array}{c}\text { ENA3 } \\
01\end{array}$ & 209 & 139 & $\begin{array}{l}48 \\
\text { Tin }\end{array}$ & 8 \\
\hline 3 & $\begin{array}{c}\text { PHB } \\
898\end{array}$ & 14 & 8 & $\begin{array}{l}48 \\
\text { Tin }\end{array}$ & 1 \\
\hline 4 & $\begin{array}{c}\text { PHC } \\
243\end{array}$ & 19 & 11 & $\begin{array}{l}48 \\
\text { Tin }\end{array}$ & 1 \\
\hline 5 & $\begin{array}{c}\text { PHZ } \\
007\end{array}$ & 19 & 4 & $\begin{array}{l}48 \\
\text { Tin }\end{array}$ & 1 \\
\hline 6 & $\begin{array}{c}\text { PHX } \\
67 \mathrm{H}\end{array}$ & 26 & 10 & $\begin{array}{l}48 \\
\text { Tin }\end{array}$ & 1 \\
\hline
\end{tabular}

Contoh perhitungan Thorughput untuk paint ENA300;

$T j=\left(\frac{293}{48}\right)+\left(\frac{157}{48}\right)=10$. aktivitas

\subsection{Perbandingan Thorughput dengan Space Requirment (T/S)}

Pada pembahasan diatas sudah didapat kebutuhan ruang atau blok $(\mathrm{Sj})$ untuk tiap paint dan jumlah aktivitas (Tj) untuk tiap paint. Hasil perhitungan (T/S) dibutuhkan untuk dijadikan patokan pada penempatan paint. Sebagai contoh perhitungan T/S pada paint ENA300 adalah:

$\frac{T}{S}=\frac{10}{4}=2,5$.aktivitas $/$ blok
Tabel 5.Perbandingan Throughput dengan Space Requirment

\begin{tabular}{|c|c|c|c|c|}
\hline No. & Code & $\begin{array}{c}\text { SR } \\
\text { Blok }\end{array}$ & Thorughput & $\mathrm{T} / \mathrm{S}$ \\
\hline 1 & $\begin{array}{c}\text { ENA30 } \\
0\end{array}$ & 4 & 10 & 2,5 \\
\hline 2 & $\begin{array}{c}\text { ENA30 } \\
1\end{array}$ & 3 & 8 & 2,7 \\
\hline 3 & $\begin{array}{l}\text { PHB } \\
898\end{array}$ & 1 & 1 & 1 \\
\hline 4 & $\begin{array}{l}\text { PHC } \\
243\end{array}$ & 1 & 1 & 1 \\
\hline 5 & $\begin{array}{c}\text { PHZ } \\
007\end{array}$ & 1 & 1 & 1 \\
\hline 6 & $\begin{array}{l}\text { PHX } \\
67 \mathrm{H}\end{array}$ & 1 & 1 & 1 \\
\hline
\end{tabular}

Penempatan produk dilakukan berdasarkan perbandingan T/S dimana hasil perbandingan yang paling besar diletakkan pada blok yang paling pendek jarak tempuhnya. Berikut adalah perangkingan paint pada tabel 6 .

Tabel 6. Perangkingan Thorughput dengan

\begin{tabular}{|c|c|c|c|c|c|}
\hline No. & Code & $T / S$ & $\mathrm{No}$ & Code & $T / S$ \\
\hline 1 & ENA & 3 & 18 & GMA & 1 \\
\hline 2 & ENA & 2,7 & 19 & EAD & 1 \\
\hline 3 & ENA & 2,5 & 20 & EGA & 1 \\
\hline 4 & $\mathrm{PH}$ & 1 & 21 & EPA & 1 \\
\hline 5 & PHB & 1 & 22 & EVA & 1 \\
\hline 6 & $\begin{array}{l}\text { PHO } \\
\text { PHC } \\
243\end{array}$ & 1 & 23 & PZ & 1 \\
\hline 7 & $\begin{array}{c}\text { PHZ } \\
007\end{array}$ & 1 & 24 & $\begin{array}{c}\text { PHE } \\
589\end{array}$ & 1 \\
\hline 8 & $\begin{array}{c}\text { PHX } \\
67 \mathrm{H}\end{array}$ & 1 & 25 & $\begin{array}{c}\text { GTA } \\
007\end{array}$ & 1 \\
\hline 9 & $\begin{array}{c}\text { PHY } \\
999\end{array}$ & 1 & 26 & $\begin{array}{c}\text { GTA } \\
220\end{array}$ & 1 \\
\hline 10 & $\begin{array}{c}\text { PHB } \\
168\end{array}$ & 1 & 27 & $\begin{array}{c}\text { GTA } \\
733\end{array}$ & 1 \\
\hline 11 & $\begin{array}{c}\text { PHZ } \\
912\end{array}$ & 1 & 28 & $\begin{array}{c}\text { EGA } \\
089\end{array}$ & 1 \\
\hline 12 & $\begin{array}{c}\text { EGA } \\
088\end{array}$ & 1 & 29 & $\begin{array}{c}\text { EPA } \\
489\end{array}$ & 1 \\
\hline 13 & $\begin{array}{c}\text { EPA } \\
493\end{array}$ & 1 & 30 & $\begin{array}{c}\text { ECD } \\
088\end{array}$ & 1 \\
\hline 14 & $\begin{array}{c}\text { EPA } \\
490\end{array}$ & 1 & 31 & $\begin{array}{c}\text { EGA } \\
237\end{array}$ & 1 \\
\hline 15 & $\begin{array}{c}\text { ECD } \\
087\end{array}$ & 1 & 32 & $\begin{array}{c}\text { EGA } \\
874\end{array}$ & 1 \\
\hline 16 & $\begin{array}{c}\text { EGA } \\
236\end{array}$ & 1 & 33 & $\begin{array}{c}\text { EPA } \\
143\end{array}$ & 1 \\
\hline 17 & $\begin{array}{c}\text { EAD } \\
087\end{array}$ & 1 & 34 & $\begin{array}{c}\text { EVA } \\
002\end{array}$ & 1 \\
\hline
\end{tabular}




\subsection{Perhitungan Jarak Perjalanan tiap Blok I/O Point}

Jarak perjalanan diukur sepanjang lintasan dengan menggunakan garis tegak lurus (orthogonal) satu dengan yang lainnya. Jumlah blok yang ada adalah 40 blok, tiap blok akan dihitung jaraknya dari titik I/O dengan garis lurus. Yang menjadi pertimbangan dalam menghitung jarak adalah lebarnya gang pada gudang. Lebar gang dapat dihitung dengan menghitung panjang diagonal dari material handling yang akan dipakai. Ada dua jenis material handling yang digunakan dalam menyimpan/mengambil produk. Ini dibedakan dari jumlah pengambilan paint dalam sekali pengangkutan.

1. Pengambilan per pallet

Pengambilan paint dilakukan per pallet, material handling yang digunakan adalah Stacker dengan ukuran 2,27 $\mathrm{m} \times 1,05 \mathrm{~m}$. Perhitungan daerah stacker dihitung dengan memperkirakan panjang diagonal stacker agar memudahakan dalam membelok pada saat mengangkat paint.

Panjangdiagonal $=\sqrt{\text { lebarstac } \mathrm{ker}^{2}+\text { panjangstac } \mathrm{ker}^{2}}$

$$
=\sqrt{(1,05)^{2}+(2,27)^{2}}=2,5 \approx 3
$$

2. Pengambilan per drum

Pengambilan dilakukan per drum, material handling yang dipakai adalahtrolly. Ukuran trolly yang digunakan adalah $0,90 \mathrm{~m} \times 0,60 \mathrm{~m}$. Dengan panjang diagonal trolly pada saat membawa paint.

Panjangdiagonal $=\sqrt{\text { lebartrolly }^{2}+\text { panjangtrolly }^{2}}$

$$
=\sqrt{(0,60)^{2}+(0,90)^{2}}=1,1
$$

Dari hasil tersebut di ambil dan diterapkan digudang adalah panjang diagonal stacker.

Tabel 7. Jarak Perjalana tiap blok ke I/O point

\begin{tabular}{cccccc}
\hline Blok & X1 & Y1 & X2 & Y2 & $\begin{array}{c}\text { Jarak } \\
(\mathrm{m})\end{array}$ \\
\hline A1 & 2 & 24 & 0,7 & 15,8 & 9,5 \\
A2 & 2 & 24 & 0,7 & 14,4 & 10,9 \\
A3 & 2 & 24 & 0,7 & 13,0 & 12,3 \\
A4 & 2 & 24 & 0,7 & 11,6 & 13,7 \\
A5 & 2 & 24 & 0,7 & 10,2 & 15,1 \\
A6 & 2 & 24 & 0,7 & 8,8 & 16,5 \\
A7 & 2 & 24 & 0,7 & 7,4 & 17,9 \\
A8 & 2 & 24 & 0,7 & 6,0 & 19,3 \\
A9 & 2 & 24 & 0,7 & 4,6 & 20,7 \\
A10 & 2 & 24 & 0,7 & 3,2 & 22,1 \\
B1 & 2 & 24 & 12,3 & 12,4 & 21,9 \\
B2 & 2 & 24 & 10,9 & 12,4 & 20,5 \\
B3 & 2 & 24 & 9,5 & 12,4 & 19,1
\end{tabular}

\begin{tabular}{llllll} 
B4 & 2 & 24 & 8,1 & 12,4 & 17,7 \\
B5 & 2 & 24 & 6,7 & 12,4 & 16,3 \\
B6 & 2 & 24 & 5,3 & 12,4 & 14,9 \\
B7 & 2 & 24 & 12,3 & 13,8 & 20,5 \\
B8 & 2 & 24 & 10,9 & 13,8 & 19,1 \\
B9 & 2 & 24 & 9,5 & 13,8 & 17,7 \\
B10 & 2 & 24 & 8,1 & 13,8 & 16,3 \\
B11 & 2 & 24 & 6,7 & 13,8 & 14,9 \\
B12 & 2 & 24 & 5,3 & 13,8 & 13,5 \\
C1 & 2 & 24 & 12,3 & 6,2 & 28,1 \\
C2 & 2 & 24 & 10,9 & 6,2 & 26,7 \\
C3 & 2 & 24 & 9,5 & 6,2 & 25,3 \\
C4 & 2 & 24 & 8,1 & 6,2 & 23,9 \\
C5 & 2 & 24 & 6,7 & 6,2 & 22,5 \\
C6 & 2 & 24 & 5,3 & 6,2 & 21,1 \\
C7 & 2 & 24 & 12,3 & 7,6 & 26,7 \\
C8 & 2 & 24 & 10,9 & 7,6 & 25,3 \\
C9 & 2 & 24 & 9,5 & 7,6 & 23,9 \\
C10 & 2 & 24 & 8,1 & 7,6 & 22,5 \\
C11 & 2 & 24 & 6,7 & 7,6 & 21,1 \\
C12 & 2 & 24 & 5,3 & 7,6 & 19,7 \\
D1 & 2 & 24 & 12,3 & 0,7 & 33,6 \\
D2 & 2 & 24 & 10,9 & 0,7 & 32,2 \\
D3 & 2 & 24 & 9,5 & 0,7 & 30,8 \\
D4 & 2 & 24 & 8,1 & 0,7 & 29,4 \\
D5 & 2 & 24 & 6,7 & 0,7 & 28,0 \\
D6 & 2 & 24 & 5,3 & 0,7 & 26,6 \\
\hline & & & & &
\end{tabular}

Perhitungan pada blok A1:

$d=|2-0,7|+|24-15,8|=9,5 m$

\subsection{Penempatan Produk dan Perhitungan Jarak Tempuh Total Tanpa Perubahan Blok dan Perubahan Blok}

Pada perhitungan jarak tempuh total tanpa perubahan blok didapat jarak tempuh pada usulan 1 yaitu sepanjang 1053,9 m.

Tabel 8. Posisi Paint pada Penempatan Usulan 1

\begin{tabular}{ccccc}
\hline Blok & $\begin{array}{c}\text { Jarak } \\
(\mathbf{m})\end{array}$ & $\begin{array}{c}\text { Kode } \\
\text { Produk }\end{array}$ & T/S & $\begin{array}{c}\text { Jarak } \\
\text { Tempuh }\end{array}$ \\
\hline A1 & 9,5 & ENA303 & 3 & 61,2 \\
A2 & 10,9 & & & \\
A3 & 12,3 & & & \\
B12 & 13,5 & ENA301 & 2,7 & 106,7 \\
A4 & 13,7 & & & \\
B6 & 14,9 & & & \\
B11 & 14,9 & ENA300 & 2,5 & 153 \\
A5 & 15,1 & & & \\
B5 & 16,3 & & & \\
B10 & 16,3 & PH046 & 2 & 32,6 \\
A6 & 16,5 & PHB898 & 1 & 16,5 \\
B4 & 17,7 & PHC243 & 1 & 17,7 \\
B9 & 17,7 & PHZ007 & 1 & 17,7 \\
A7 & 17,9 & PHX67H & 1 & 17,9 \\
B3 & 19,1 & PHY999 & 1 & 19,1 \\
B8 & 19,1 & PHB168 & 1 & 19,1 \\
A8 & 19,3 & PHZ912 & 1 & 19,3 \\
C12 & 19,7 & EGA088 & 1 & 19,7 \\
B2 & 20,5 & EPA493 & 1 & 20,5 \\
B7 & 20,5 & EPA490 & 1 & 20,5 \\
\hline
\end{tabular}




\begin{tabular}{ccccc}
\hline A9 & 20,7 & ECD087 & 1 & 20,7 \\
C6 & 21,1 & EGA236 & 1 & 21,1 \\
C11 & 21,1 & EAD087 & 1 & 21,1 \\
B1 & 21,9 & GMA131 & 1 & 21,9 \\
A10 & 22,1 & EAD087 & 1 & 22,1 \\
C5 & 22,5 & EGA873 & 1 & 22,5 \\
C10 & 22,5 & EPA142 & 1 & 22,5 \\
C4 & 23,9 & EVA004 & 1 & 23,9 \\
C9 & 23,9 & PZ681 & 1 & 23,9 \\
C3 & 25,3 & PHE589 & 1 & 25,3 \\
C8 & 25,3 & GTA007 & 1 & 25,3 \\
D6 & 26,6 & GTA220 & 1 & 26,6 \\
C2 & 26,7 & GTA733 & 1 & 26,7 \\
C7 & 26,7 & EGA089 & 1 & 26,7 \\
D5 & 28 & EPA489 & 1 & 28 \\
C1 & 28,1 & ECD088 & 1 & 28,1 \\
D4 & 29,4 & EGA237 & 1 & 29,4 \\
D3 & 30,8 & EGA874 & 1 & 30,8 \\
D2 & 32,2 & EPA143 & 1 & 32,2 \\
D1 & 33,6 & EVA002 & 1 & 33,6 \\
\hline \multicolumn{5}{c}{ Jarak Total } \\
\hline
\end{tabular}

Total perjalanan yang dibutuhkan dalam gudang produk paint untuk memasukkan dan memindahkan seluruh jenis paint yang ada pada gudang dengan perubahan blok usulan 2 didapat 954,3 m.

Tabel 9. Posisi Paint pada Penempatan Usulan 2

\begin{tabular}{|c|c|c|c|c|}
\hline Blok & $\begin{array}{c}\text { Jarak } \\
(\mathbf{m})\end{array}$ & $\begin{array}{c}\text { Kode } \\
\text { Produk }\end{array}$ & $\mathbf{T} / \mathbf{S}$ & $\begin{array}{c}\text { Jarak } \\
\text { Tempuh }\end{array}$ \\
\hline D4 & 5,3 & \multirow{2}{*}{ ENA303 } & \multirow{2}{*}{3} & \multirow{2}{*}{36} \\
\hline D5 & 6,7 & & & \\
\hline D6 & 8,1 & \multirow{3}{*}{ ENA301 } & \multirow{3}{*}{2,7} & \multirow{4}{*}{106,11} \\
\hline D3 & 8,6 & & & \\
\hline A1 & 9,5 & & & \\
\hline D2 & 10 & \multirow{4}{*}{ ENA300 } & \multirow{4}{*}{2,5} & \\
\hline $\mathrm{A} 2$ & 10,9 & & & \multirow{3}{*}{220,5} \\
\hline D1 & 11,4 & & & \\
\hline B12 & 11,8 & & & \\
\hline A3 & 12,3 & PH046 & 2 & 24,6 \\
\hline B6 & 13,2 & РHB898 & 1 & 13,2 \\
\hline B11 & 13,7 & PHC243 & 1 & 13,2 \\
\hline A4 & 14,6 & PHZ007 & 1 & 13,7 \\
\hline B5 & 14,6 & РHX67H & 1 & 14,6 \\
\hline B10 & 15,1 & PHY999 & 1 & 14,6 \\
\hline A5 & 16 & PHB168 & 1 & 15,1 \\
\hline B4 & 16 & PHZ912 & 1 & 16 \\
\hline B9 & 16,5 & EGA088 & 1 & 16 \\
\hline A6 & 17,4 & EPA493 & 1 & 16,5 \\
\hline B3 & 17,4 & EPA490 & 1 & 17,4 \\
\hline B8 & 17,6 & ECD087 & 1 & 17,4 \\
\hline $\mathrm{C} 12$ & 17,9 & EGA236 & 1 & 17,6 \\
\hline A7 & 18,8 & EAD087 & 1 & 17,9 \\
\hline B2 & 18,8 & GMA131 & 1 & 18,8 \\
\hline B7 & 19 & EAD087 & 1 & 18,8 \\
\hline C6 & 19 & EGA873 & 1 & 19 \\
\hline $\mathrm{C} 11$ & 19,3 & EPA142 & 1 & 19 \\
\hline A8 & 20,2 & EVA004 & 1 & 19,3 \\
\hline B1 & 20,4 & PZ681 & 1 & 20,2 \\
\hline
\end{tabular}

\begin{tabular}{ccllc}
\hline C5 & 20,4 & PHE589 & 1 & 20,4 \\
C10 & 20,7 & GTA007 & 1 & 20,4 \\
A9 & 21,8 & GTA220 & 1 & 20,7 \\
C4 & 21,8 & GTA733 & 1 & 21,8 \\
C9 & 21,8 & EGA089 & 1 & 21,8 \\
A10 & 22,1 & EPA489 & 1 & 22,1 \\
C3 & 23,2 & ECD088 & 1 & 23,2 \\
C8 & 23,2 & EGA237 & 1 & 23,2 \\
C2 & 24,6 & EGA874 & 1 & 24,6 \\
C7 & 24,6 & EPA143 & 1 & 24,6 \\
C1 & 26 & EVA002 & 1 & 26 \\
\hline \multicolumn{5}{c}{ Jarak Total } \\
\hline \multicolumn{5}{c}{}
\end{tabular}

Sehingga dari hasil tersebut harus dilakukan perubahan blok sesuai dengan usulan 2. Dengan layout penempatan paint sebagai berikut:

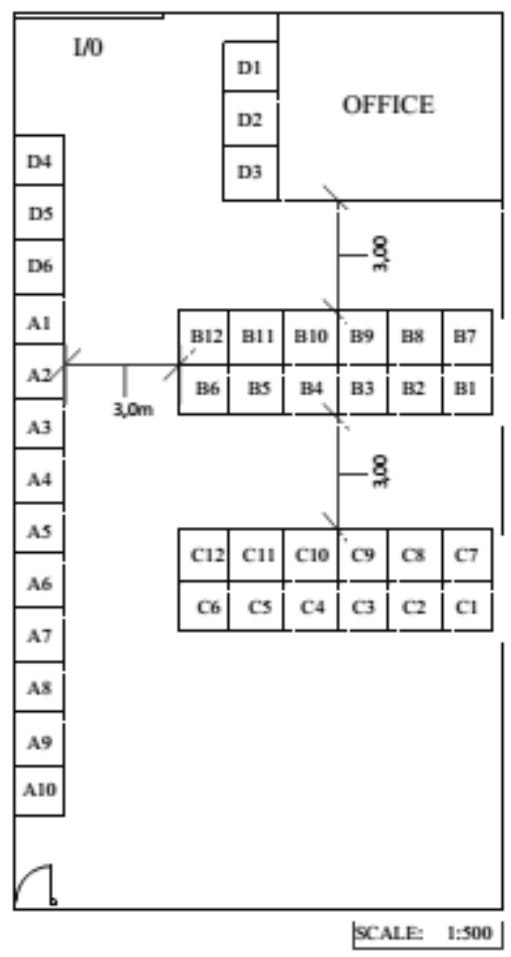

Gambar 4. Layout usulan

Penempatan paint dilakukan dengan menempatkan produk dengan nilai T/S tertinggi pada blok dengan jarak tempuh terkecil, lalu tertinggi kedua pada blok terkecil kedua, dan seterusnya. Penempatan yang dipilih adalah usulan perbaikan kedua. Dari tabel 9 didapat bahwa paint yang memiliki nilai T/S tertinggi adalah ENA303 yaitu 3, dan membutuhkan 2 blok penyimpanan. Sedangkan untuk blok penyimpanannya adalah blok D4 dan D5 karena memiliki jarak tempuh terkecil dari titik I/O. Jenis paint lainnya akan ditempatkan pada blokblok yang tersedia sesuai dengan besarnya nilai T/S dari setiap paint dan besar jarak tempuh tiap 
bloknya.

\section{Kesimpulan}

Dari hasil penelitian dan analisa data yang telah dilakukan maka dapat diambil beberapa kesimpulan sebagai berikut:

1. Total jarak material handling pada kondisi gudang saat ini adalah 1305,1 m sedangkan total jarak material handling yang perbaikan layout untuk usulan 1 yaitu $1137,07 \mathrm{~m}$, dan untuk kondisi usulan 2 sebesar 933,28 m.

2. Turunnya nilai total jarak material handling yang terjadi pada usulan 1 (penerapan metode dedicated storage tanpa merubah penempatan blok) sebesar 12,87 \%, sedangkan pada usulan2 (penerapan metode dedicated storage melakukan perubahan penempatan blok) lebih tinggi yaitu 28,5\%. Sehingga perbaikan usulan kedua lebih baik digunakan sebagai acuan merelayout tata letak gudang tersebut.

\section{Daftar Referensi}

Aliudin, Tb M.A., (2015). Usulan Perbaikan Tata Letak Gudang Produk Drum OliMenggunakan Metode Dedicated Storage Di PT XYZ, Jurnal Teknik Industri .3(1).

Efrataditama, A., dan S.Setio Wigati, (2016).Perancangan Tata Letak Gudang DenganMetode Dedicated Storage Di toko Listrik Anugrah Jaya, Jurnal Teknik Industri.2337(4349): 272-284.

Hadiguna, R.A \& Heri Setiawan.(2008). Tata Letak Pabrik. Andi Offset. Yogyakarta.

Permana, I.H., Muhammad Adha Ilham \& Evi Febianti, (2013). Relayout Tata Letak GudangProduk Jadi Menggunakan Dedicated Storage, Jurnal Teknik Industri. 1(4): $272-277$.

Wignjosoebroto, S. (2009). Tata Letak Pabrik Dan Pemindahan Bahan. Guna Widya. Edisi3. Surabaya. 